\title{
Initiation of coconut cell suspension culture from shoot meristem derived embryogenic calli: A preliminary study
}

\author{
U. Bhavyashree, K. Lakshmi Jayaraj, K. S. Muralikrishna, K. K. Sajini, M. K. Rajesh, \\ Anitha Karun*
}

Division of Crop Improvement, ICAR-Central Plantation Crop Research Institute, Kasaragod, Kerala, India

Received: 19.01.2016
Revised: 25.01.2016
Accepted: 29.01.2016
Published: 29.01.2016
*Address for
Correspondence:
Anitha Karun, Division
of Crop Improvement,
ICAR-Central Plantation
Crop Research Institute,
Kasaragod - 671 124,
Kerala, India.
E-mail: anithakarun2013@
gmail.com

\begin{abstract}
An attempt was made to establish highly competent embryogenic cell suspension culture in coconut, a species recalcitrant to in vitro culture. Embryogenic calli were initiated from shoot meristem explants of coconut. Y3 medium supplemented with 2.4-D $(4.5 \mu \mathrm{M})$ and glutamine $(34.2 \mu \mathrm{M})$ was found to be the best medium to initiate cell suspension. Growth evaluation was done by packed cell volume (PCV) and it was found that maximum growth volume of $9.9 \%$ was reached at 200 days of culture initiation. About $52 \%$ of viable cells were detected through fluorescent microscopy. Cell aggregation was noticed in $\mathrm{Y} 3$ medium supplemented with glutamine (34.2 $\mu \mathrm{M})$, malt extract $(100 \mathrm{mg} / \mathrm{l})$, biotin $(40.9 \mu \mathrm{M})$ and kinetin $(9.3 \mu \mathrm{M})$, but further progress could not be achieved. It was also observed that embryogenic calli were not of a friable type, but were associated with densely aggregated cells. Because of its hard nature, we were unsuccessful to obtain high quality cell suspension.
\end{abstract}

KEY WORDS: KEYWORDS: Coconut, shoot meristem, embryogenic calli, cell suspension
Coconut (Cocos nucifera L.) is a woody species, belonging to the family Arecaceae. Since the every part of the coconut tree is made into universally used products, it is popularly known as "tree of life." Since the coconut is a recalcitrant species with respect to tissue culture, only limited success has been achieved, and the protocols lack repeatability (Rajesh et al., 2005; 2014). It is very important to make use of a protocol that successfully solves the major constraints during somatic embryogenesis and its regeneration. It is possible to establish highly competent embryogenic cell suspension cultures to overcome the major bottlenecks during in vitro culture (Wang et al., 2002). In a cell suspension, callus is suspended in a liquid callus induction media, containing all required nutrients and elements, to allow for optimal growth which acts to turn all cells into undifferentiated cells (King, 1984). Suspension cultures consisting of proembryonic masses established from calli shows a high competency for somatic embryogenesis (Fki et al., 2003).

In this present study, embryogenic calli initiated from coconut shoot meristem explants were utilized for the establishment of cell suspension cultures. Initially, a date palm suspension culture protocol (Fki et al., 2003) was followed in which $500 \mathrm{mg}$ of coconut embryogenic calli, derived from shoot meristem explants, was weighed and crushed with tissue grinder and inoculated to a full strength $\mathrm{Y} 3$ medium supplemented with 2,4-D $(4.5 \mu \mathrm{M})$, glutamine $(34.2 \mu \mathrm{M}), \mathrm{KH}_{2} \mathrm{PO}_{4}(882.3 \mu \mathrm{M})$, adenine $(222 \mu \mathrm{M})$, and activated charcoal $(300 \mathrm{mg} / \mathrm{l})$. About $30 \mathrm{ml}$ of culture media was poured to $150 \mathrm{ml}$ of Erlenmeyer flask. Cultures were kept in a rotary shaker at $120 \mathrm{rpm}$ at $28^{\circ} \mathrm{C} \pm 2{ }^{\circ} \mathrm{C}$. Sub-cultures were carried out at 7 days intervals 5-6 times. After this, cultures were subcultured to a medium containing glutamine $(34.2 \mu \mathrm{M})$, $\mathrm{KH}_{2} \mathrm{PO}_{4}(882.3 \mu \mathrm{M})$, adenine $(222 \mu \mathrm{M})$, and activated charcoal $(300 \mathrm{mg} / \mathrm{l})$. In this stage, cultures were subcultured at 20 days intervals. Cell initiation commenced after 75 days of culture incubation, and the cells were observed to be highly vacuolated and elongated. However, in the case of date palm, highly heterogeneous suspension was formed which consists of cells at various stages of differentiation, and large number of somatic embryos were formed in a medium supplemented with 2,4-D $(4.5 \mu \mathrm{M})$ (Fki et al., 2003). The coconut suspensions were transferred to a medium supplemented with thidiazuron 
$(4.5 \mu \mathrm{M})$ and spermine $(50 \mu \mathrm{M})$. However, it was noticed that, in this medium, proper cell multiplication was not formed.

Experiments were also conducted to study the effect of different growth regulators on coconut cell suspensions. Eeuwen's Y3 (1976) basal media supplemented with varying concentrations of 2,4-D (0.45-45 $\mu \mathrm{M})$ and picloram $(0.41-41 \mu \mathrm{M})$ in combination with 6-benzyle adenine $(2.22 \mu \mathrm{M})$ were prepared. Sub-cultures were carried out at 7 days intervals to the same medium combination. Cell initiation was observed in all the media combinations. Based on the cell count, it was noticed that medium supplemented with 2,4-D $(4.5 \mu \mathrm{M})$ showed a better response compared to rest of the media combinations. In oil palm, in medium supplemented with 2,4-D $(4.5 \mu \mathrm{M})$ in combination with naphthalene acetic acid (NAA) $(0.5 \mu \mathrm{M})$, the good proliferation of cell suspension was achieved (Tarmizi et al., 2002). Furthermore, in the case of oil palm, fine suspensions, on transfer to media supplemented with 2,4-D $(0.45 \mu \mathrm{M})$, formed cell aggregates (Palanyandy et al., 2013). In the present study, the suspensions obtained were transferred to a media supplemented with a high concentration of glutamine $(34.2 \mu \mathrm{M})$. Cell multiplication increased, but cell aggregates were not formed from these cultures. Percentage of round shaped cells was less compared to elongated cells. The proliferation of somatic embryos in date palm was observed in a medium containing 2,4-D $\left(4.5 \times 10^{-7} \mathrm{M}\right)$, glutamine $\left(6.7 \times 10^{-4} \mathrm{M}\right)$, and abscisic acid $\left(10^{-5} \mathrm{M}\right)$ (Zouine et al., 2005).

We have also carried out further experiments to achieve cell aggregation in coconut with high concentrations of 2,4-D (90, 180, $270 \mu \mathrm{M})$ (Table 1). Cultures in medium supplemented with 2,4-D $(180 \mu \mathrm{M})$ developed into the fine suspension. However, very few number of cell aggregates were observed (Figure 1a). Experiments were also conducted to study the effect of different growth supplements viz., full strength Y3 basal media supplemented with sucrose ( $50 \mathrm{~g})$, glutamine $(34.2 \mu \mathrm{M})$, malt extract $(100 \mathrm{mg} / \mathrm{l})$, biotin $(40.9 \mu \mathrm{M})$, and kinetin $(9.3 \mu \mathrm{M})$ (Table 2). Media and cell suspensions were added in $100 \mathrm{ml}$ of Erlenmeyer flask in 3:1 ratio. Cell number and shape of the cells were observed under a microscope. A prominent nucleus was observed inside the cell. Each cell showed high nucleo-cytoplasmic ratio (Figure 1b). Round shaped cells were more in number compared to elongated cells. Based on observations under the microscope, after 30 days of incubation, in $40 \%$ of the cultures, cell aggregates were noticed (Figure 1c). In
Table 1: Media combination with high concentration of 2,4-D

\begin{tabular}{lccc}
\hline $\begin{array}{l}\text { Concentration } \\
\text { of } 2,4-D(\mu \mathrm{M})\end{array}$ & $\begin{array}{c}\text { After } \\
45 \text { days }\end{array}$ & $\begin{array}{c}\text { After } \\
30 \text { days }\end{array}$ & $\begin{array}{c}\text { After } \\
30 \text { days }\end{array}$ \\
\hline 270 & 180 & 90 & 0 \\
180 & 90 & 0 & 0 \\
90 & 0 & 0 & 0 \\
\hline
\end{tabular}

Table 2: Media combination with various growth supplements

\begin{tabular}{lcccc}
\hline Time period & $\begin{array}{c}\text { Glutamine } \\
(\mu \mathrm{M})\end{array}$ & $\begin{array}{c}\text { Malt extract } \\
(\mathrm{mg} / \mathrm{l})\end{array}$ & $\begin{array}{c}\text { Biotin } \\
(\mu \mathrm{M})\end{array}$ & $\begin{array}{c}\text { Kinetin } \\
(\mu \mathrm{M})\end{array}$ \\
\hline Initial inoculation & 34.2 & 100 & 40.9 & 9.3 \\
After 15 days & 34.2 & 100 & 40.5 & 9.3 \\
After 30 days & 34.2 & 50 & 20.25 & 9.3 \\
After 45 days & 34.2 & 50 & 20.25 & 4.65 \\
After 60 days & 34.2 & - & - & - \\
\hline
\end{tabular}

case of banana suspension cultures, initially Murashige and Skoog liquid medium supplemented with $4.5 \mu \mathrm{M}$ 2,4-D, $4.1 \mu \mathrm{M}$ biotin, $100 \mathrm{mg} / \mathrm{l}$ malt extract, $680 \mu \mathrm{M}$ glutamine, and $130 \mu \mathrm{M}$ sucrose were used to obtain cell aggregates, which later were transferred to regeneration media with same constituents except 2,4-D (Georget et al., 2000). However, it was suggested that in the case of banana, 2,4-D hindered the development of protoderms in the proembryos.

Cell viability was tested with FDA stain and 52\% of viable cells were detected by a fluorescent microscope (Figure 1d). Growth evaluation was done by packed cell volume (PCV) tube (Figure 1e). About $500 \mu \mathrm{l}$ of cell suspension was added to PCV tube and centrifuged for $5000 \mathrm{rpm}$ for $1 \mathrm{~min}$. PCV test was conducted, and data were recorded as a percentage of cell mass of the total centrifuged volume. Maximum growth volume (9.9\%) was reached 200 days after suspension culture initiation (Table 3 and Figure 1f). From the initiation time of suspension culture, the lag phase was extended and the highest growth rate observed in the exponential phase (i.e. in $28^{\text {th }}$ week). After $28^{\text {th }}$ weeks, growth deceleration had occurred. In date palm, it was reported that after 8 weeks of culture incubation, growth volume was increased up to $12.1 \%$ (Al-Khayri, 2012).

The suspension obtained in the present study was transferred to a full strength Y3 semisolid medium (agar $0.75 \mathrm{~g} / \mathrm{l})$ to achieve further progress. Suspension and semisolid media were added in various ratios viz., $1: 1,1: 2$, and 2:1. Much progress was not observed in these cultures. Further manipulation was made in suspension medium by the incorporation of $\mathrm{AdSO}_{4}(222 \mu \mathrm{M})$ and zeatin $(1 \mu \mathrm{M})$. In this treatment, the number of cell aggregates increased. However, further development was not achieved. In the case of banana, embryogenic clumps developed into 


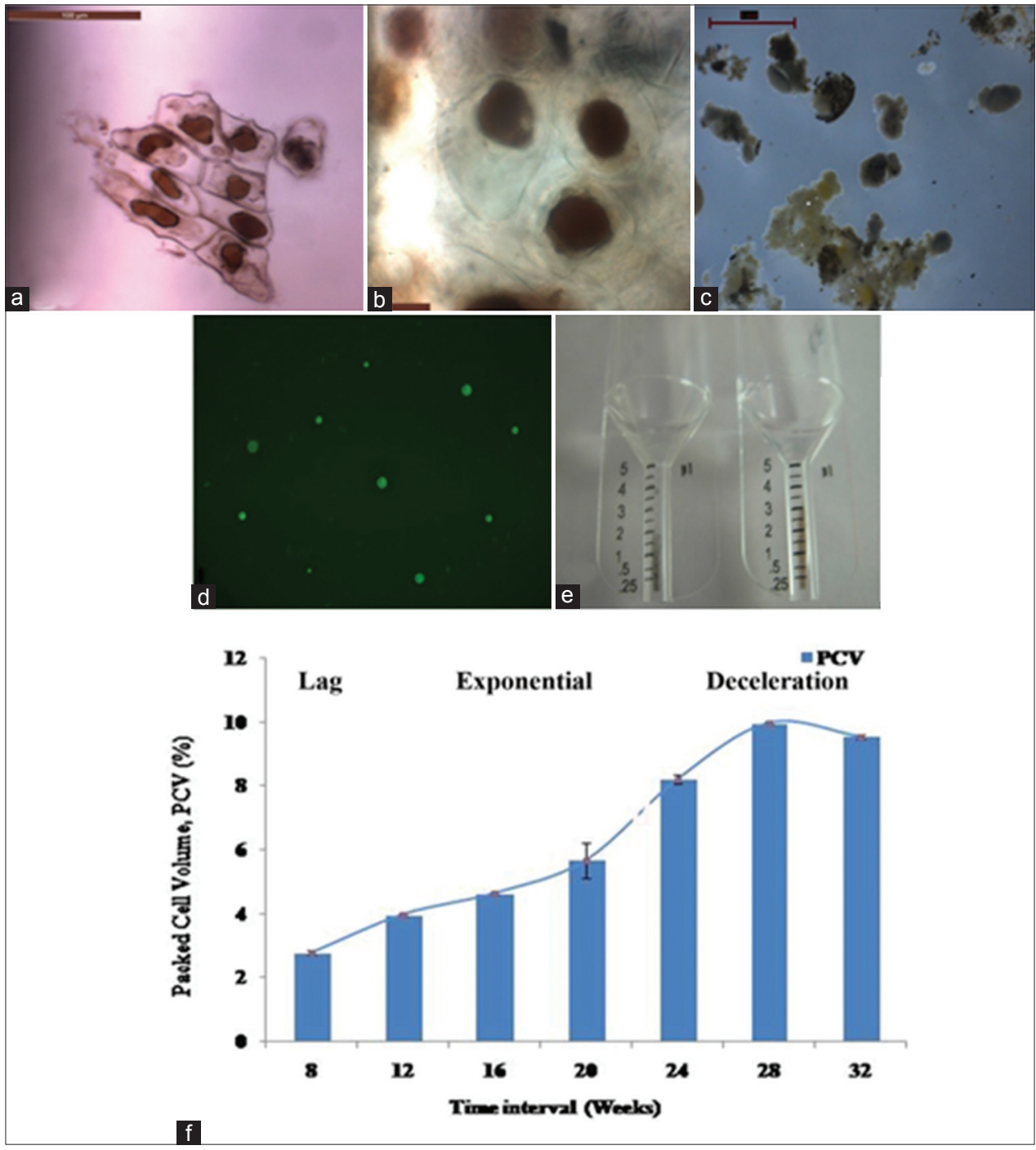

Figure 1: (a) Cell aggregate formation. (b) Cells showing high nucleo-cytoplasmic ratio. (c) Cell aggregates observed under stereo microscope. (d) Viable cells observed under fluorescent microscope. (e) Packed cell volume (PCV) evaluation. (f) The growth curve of coconut cell suspension showing PCV in relation to time (Lag phase, exponential phase, deceleration phase)

Table 3: PCV of various media combinations

\begin{tabular}{|c|c|c|c|c|c|c|c|c|}
\hline Media & 30 & 60 & 90 & 120 & 150 & 175 & 200 & 230 \\
\hline Y3 & $00 \pm 0.00$ & $0.00 \pm 0.00$ & $0.03 \pm 0.03$ & $0.07 \pm 0.05$ & $0.10 \pm 0.05$ & $0.16 \pm 0.05$ & $0.47 \pm 0.24$ & $0.46 \pm 0.24$ \\
\hline $\mathrm{Y} 3+2,4-\mathrm{D}(0.1 \mathrm{mg} / \mathrm{l})$ & $00 \pm 0.00$ & $0.93 \pm 0.06$ & $1.50 \pm 0.05$ & $2.00 \pm 0.05$ & $2.63 \pm 0.20$ & $3.20 \pm 0.27$ & $.43 \pm 0.34$ & $2.97 \pm 0.21$ \\
\hline $\mathrm{Y} 3+2,4-\mathrm{D}(1.0 \mathrm{mg} / \mathrm{l})$ & $00 \pm 0.00$ & $2.77 \pm 0.08$ & $3.97 \pm 0.03$ & $4.36 \pm 0.05$ & $5.67 \pm 0.57$ & $8.20 \pm 0.14$ & $9.97 \pm 0.03$ & $9.53 \pm 0.06$ \\
\hline $\mathrm{Y} 3+2,4-\mathrm{D}(10 \mathrm{mg} / \mathrm{l})$ & $00 \pm 0.00$ & $1.17 \pm 0.03$ & $1.47 \pm 0.03$ & $2.10 \pm 0.14$ & $2.53 \pm 0.03$ & $3.50 \pm 0.18$ & $3.87 \pm 0.03$ & $3.70 \pm 0.14$ \\
\hline $\mathrm{Y} 3+2,4-\mathrm{D}(0.1 \mathrm{mg} / \mathrm{l})+\mathrm{BAP}(0.5 \mathrm{mg} / \mathrm{l}))$ & $0.00 \pm 0.00$ & $2.53 \pm 0.03$ & $3.70 \pm 0.05$ & $4.43 \pm 0.08$ & $5.87 \pm 0.20$ & $7.23 \pm 0.34$ & $9.00 \pm 0.05$ & $8.43 \pm 0.11$ \\
\hline $\mathrm{Y} 3+2,4-\mathrm{D}(1.0 \mathrm{mg} / \mathrm{l})+\mathrm{BAP}(0.5 \mathrm{mg} / \mathrm{l})$ & $0.00 \pm 0.00$ & $1.53 \pm 0.03$ & $2.20 \pm 0.14$ & $2.87 \pm 0.17$ & $3.47 \pm 0.21$ & $3.63 \pm 0.24$ & $4.03 \pm 0.20$ & $3.73 \pm 0.21$ \\
\hline $\mathrm{Y} 3+2,4-\mathrm{D}(10 \mathrm{mg} / \mathrm{l})+\mathrm{BAP}(0.5 \mathrm{mg} / \mathrm{l})$ & $0.00 \pm 0.00$ & $2.03 \pm 0.03$ & $2.50 \pm 0.05$ & $3.00 \pm 0.05$ & $3.83 \pm 0.06$ & $4.20 \pm 0.05$ & $4.90 \pm 0.14$ & $4.67 \pm 0.13$ \\
\hline $\mathrm{Y} 3+\mathrm{Pic}(0.1 \mu \mathrm{M})$ & $0.00 \pm 0.00$ & $1.37 \pm 0.06$ & $1.90 \pm 0.05$ & $2.13 \pm 0.12$ & $2.90 \pm 0.05$ & $3.07 \pm 0.03$ & $3.93 \pm 0.03$ & $3.73 \pm 0.08$ \\
\hline $\mathrm{Y} 3+\mathrm{Pic}(1 \mu \mathrm{M})$ & $0.00 \pm 0.00$ & $2.77 \pm 0.03$ & $3.67 \pm 0.03$ & $4.57 \pm 0.03$ & $6.10 \pm 0.05$ & $7.73 \pm 0.11$ & $9.17 \pm 0.03$ & $8.70 \pm 0.14$ \\
\hline $\mathrm{Y} 3+\mathrm{Pic}(10 \mu \mathrm{M})$ & $0.00 \pm 0.00$ & $1.93 \pm 0.03$ & $2.20 \pm 0.05$ & $2.80 \pm 0.05$ & $3.33 \pm 0.03$ & $3.73 \pm 0.03$ & $4.20 \pm 0.10$ & $3.77 \pm 0.08$ \\
\hline $\mathrm{Y} 3+\mathrm{Pic}(0.1 \mu \mathrm{M})+\mathrm{BAP}(0$ & $0.00 \pm 0.00$ & $1.93 \pm 0.03$ & $2.40 \pm 0.05$ & $2.87 \pm 0.03$ & $3.07 \pm 0.03$ & $3.70 \pm 0.05$ & $4.17 \pm 0.17$ & $3.67 \pm 0.08$ \\
\hline $\mathrm{Y} 3+\mathrm{Pic}(1 \mu \mathrm{M})+\mathrm{BAP}(0.5 \mathrm{mg} / \mathrm{l})$ & $0.00 \pm 0.00$ & $2.00 \pm 0.00$ & $2.40 \pm 0.00$ & $3.00 \pm 0.00$ & $3.30 \pm 0.00$ & $3.83 \pm 0.03$ & $4.53 \pm 0.03$ & $4.13 \pm 0.03$ \\
\hline $\mathrm{Y} 3+\mathrm{Pic}(10 \mu \mathrm{M})+\mathrm{BAP}(0.5 \mathrm{mg} / \mathrm{l})$ & $0.00 \pm 0.00$ & $2.37 \pm 0.03$ & $3.37 \pm 0.18$ & $4.00 \pm 0.00$ & $5.23 \pm 0.03$ & $6.60 \pm 0.09$ & $8.50 \pm 0.14$ & $8.23 \pm 0.16$ \\
\hline
\end{tabular}

Level of significance is represented by CD at $5 \%$. CD at $5 \%$ : Media $0.14 *$ Days $0.11^{*}$ MediaxDays $0.37 *$. PCV: Packed cell volume, BAP: 6-benzyle adenine

somatic embryos by supplementing the media with NAA $(1.1 \mu \mathrm{M})$, adenine $(0.7 \mu \mathrm{M})$, kinetin $(0.5 \mu \mathrm{M})$, and zeatin $(0.2 \mu \mathrm{M})$ (Cote et al., 2000).
In the case of coconut, embryogenic calli were not friable type and were associated with densely aggregated cells. Because of the hard nature of the embryogenic calli, we 
were unsuccessful in obtaining high-quality suspension to initiate somatic embryogenesis. The results of the study revealed that future research should be directed toward initiation of friable calli in coconut.

\section{ACKNOWLEDGMENTS}

The authors thank Indian Council for Agricultural Research (ICAR) for funding this research.

\section{REFERENCES}

Al-Khayri JM. Determination of the date palm cell suspension growth curve, optimum plating efficiency, and influence of liquid medium on somatic embryogenesis. Emir J Food Agric 2012;24:444-55.

Cote FX, Folliot M, Domergue R, Dubios C. Field performance of embryogenic cell suspension derived banana plants (Musa AAA, cv. Grande naine). Emphytica 2000;112:245-51.

Eeuwens CJ. Mineral requirements for growth and callus initiation of tissue explants excised from mature coconut (Cocos nucifera L.) and date (Phoenix dactylifera L.) palms cultured in vitro. Physiol Plant 1976;36:23-8.

Fki L, Masmoudi R, Drira N, Rival A. An optimized protocol for plant regeneration from embryogenic suspension cultures of date palm, Phoenix dactylifera L. cv. Deglet Nour. Plant Cell Rep 2003;21:517-24.

Georget R, Domergue R, Ferrière N, Côte FX. Morphohistological study of the different constituents of a banana (Musa AAA, cv. Grande naine) embryogenic cell suspension. Plant Cell Rep 2000;19:748-54.

King PJ. Induction and maintenance of cell suspension cultures. In:Vasil IK, editor. Cell Culture and Somatic Cell Genetics of Plants. Vol. 1. New York: Academic Press; 1984. p. $130-8$.

Rajesh MK, Radha E, Sajini KK, Karun A, Parthasarathy VA. Plant regeneration through organogenesis and somatic embryogenesis from plumular explants of coconut (Cocos nucifera L.). J Plant Crops 2005;33:9-17.

Rajesh MK, Radha E, Sajini KK, Karun A. Polyamine-induced somatic embryogenesis and plantlet regeneration in vitro from plumular explants of dwarf cultivars of coconut (Cocos nucifera L.). Indian J Agric Sci 2014;84:527-30.

Palanyandy SR, Suranthran P, Gantait S, Sinniah UR, Subramaniam S, Aziz MA, et al. In vitro developmental study of oil palm (Elaeis guineensis Jacq.) polyembryoids from cell suspension using scanning electron microscopy. Acta Physiol Plant 2013;35:1727-33.

Tarmizi AH. MPOB Liquid Culture System. MPOB Information Series 2002; No. 138.

Wang ZY, Scott M, Hopkins A. Plant regeneration from embryogenic cell suspension cultures of Lolium temulentum. InVitro Cell Dev Biol Plant 2002;38:446-50.

Zouine J, Mounir EB, Abdelilah M, Jean-Luc V, Ismail EH. Proliferation and germination of somatic embryos from embryogenic suspension cultures in Phoenix dactylifera. Plant Cell Tissue Organ Cult 2005;82:83-92. 